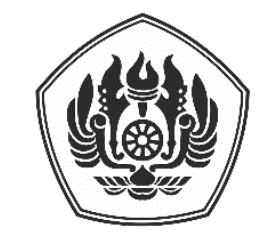

\author{
Padjadjaran Journal of International Law \\ ISSN: 2549-2152, EISSN: 2549-1296 \\ Volume 4, Number 2, June 2020
}

\title{
The Failure of United Nations System under International Law: Its Contribution to Calamity and Ruin of the Rohingya Case
}

\author{
Renata Christha Auli* , Garry Gumelar Pratama**
}

\begin{abstract}
The tensions between Muslim and Buddhist communities in Rakhine, Myanmar have escalated and became the international spotlight. Massacre in the Rohingya is a serious violation of human rights. In accordance with the functions of the United Nation, this international organization is expected to prevent and eliminate crimes against humanity that occur in the Rohingya. One of the main organs in charge of maintaining international peace and security is the UN Security Council. However, the fact that the United Nations failed to carry out its duties was because Russia has veto power and has blocked the statement which was expressed by UN Security council concerning this situation to punish Myanmar in resolving the Rohingya case, solely due to the political relationship between Russia and Myanmar. The failure of the United Nations is the world's debt to the Rohingya tribe, accordingly to redeem the debt it is needed reform of the UN Security Council.
\end{abstract}

Keywords: Humanitarian Crimes, Rohingya, Security Council, United Nations, Veto

\section{Kegagalan Sistem Perserikatan Bangsa-Bangsa dalam Hukum Internasional: Kontribusi atas Bencana dalam Kasus Rohingya}

\begin{abstract}
Abstrak
Perseteruan yang terjadi antara umat Muslim dan Buddha di Rakhine, Myanmar, kembali terjadi dan menjadi sorotan dunia internasional. Pembantaian di Rohingya merupakan pelanggaran berat terhadap hak asasi manusia. Perserikatan Bangsa- Bangsa (PBB) merupakan organisasi internasional yang diharapkan dapat mencegah dan menghapus kejahatan terhadap kemanusiaan yang terjadi di Rohingya, sesuai dengan fungsi dari Perserikatan Bangsa-Bangsa. Salah satu organ utama yang bertugas untuk menjaga perdamaian dan keamanan internasional adalah Dewan Keamanan PBB. Namun fakta yang terjadi PBB gagal dalam menjalankan tugasnya karena Rusia terus melakukan veto terhadap Resolusi Dewan Keamanan PBB untuk menghukum Myanmar dalam penyelesaian kasus Rohingya, karena sematamata hubungan politik antara Rusia dengan Myanmar. Kegagalan PBB merupakan utang dunia terhadap suku Rohingya, sehingga untuk dapat menebus utang tersebut diperlukan reformasi Dewan Keamanan PBB.
\end{abstract}

Kata Kunci: Dewan Keamanan, Kejahatan Kemanusiaan, Perserikatan Bangsa- Bangsa, Rohingya, Veto

PADJADJARAN JOURNAL OF INTERNATIONAL LAW Volume 4 Issue 2 Year 2020 [ISSN 2549-2152] [e-ISSN 2549-1296]

* Researcher at the Indonesian Center for Air and Space Law (ICASL); Member of International Law Association (ILA), Indonesian Branch, Jalan Imam Bonjol No. 21 Kota Bandung, renata_christha@yahoo.co.id.

** Researcher and Secretary at the Indonesian Center for Air and Space Law (ICASL); Member of International Law Association (ILA), Indonesian Branch, Jalan Imam Bonjol No. 21 Kota Bandung, pratama.garry@gmail.com. 


\section{A. INTRODUCTION}

The United Nations' investigators declare violence in Myanmar leads to crimes against humanity as well as ethnic cleansing. However, Suu Kyi rejected the accusations. Aung San Suu Kyi does not believe that ethnic cleansing exists. On the opposite, Aung San Suu Kyi argued that she was probing with a military operation against Bangladesh extremists. This denial makes the UN Human Rights Council, as part of the General Assembly subsidiary institution, incapable to carry on its resolution by interpreting Article 1 (2) of the United Nations Charter was not made to intervene in the sovereignty of any country ${ }^{1}$. it shows that each resolution of the General Assembly can be received or rebuffed by a concerned country. This kind of situation often makes the UNGA not easy to intercede in tension areas. To surmount this 'regulatory' hurdle, in 2005, the UN General Assembly authorized a conflict-resolution policy known as the Responsibility to Protect (R2P). Through the mechanism, the UN no longer sees sovereignty rigidly, Instead, in order to resolve the humanitarian crisis, interference can be taken out as long as it requires the government being pursued by the resolution. The problem with this policy is that the implementation still hinges on UN Security Council resolutions whereas the Security Council itself has not succeeded in making a resolution to resolve the Rakhine conflict.

The abovementioned resolution is in line with the very purpose of the United Nations itself which are ${ }^{2}(1)$ international peace and security maintenance (2) friendly relations among nations developments; (3) international cooperation achievement in

United Nations Charter 1945

Ibid.

Rebecca Wright, "Return to Rakhine: Genocide Never Happened in This Country", https://edition.cnn.com/2018/10/17/asia/insiderakhine-state-intl/index.html, accessed on the $20^{\text {th }}$ of December 2018. solving international challenges; and (4) actions of nations harmonization in the attainment of these common ends. Regardless of all the United Nations purposes, the UN has not been able to resolve the conflict in Rakhine, unless the UN Security Council is once again discussing resolutions, countries like China and Russia are willing to relax their resistance. ${ }^{3}$ Under the authority of Articles 6 as well as 8 of the UN Charter 1945, the UN has the duty to take on action to protect an inhabitant from genocide and crimes agains humanity. One of the procedures is over the UN Security Council and the UN General Assembly resolution. ${ }^{4}$

Still, in the Rohingya case, the United Nations released merely two resolutions. Earliest, the United Nations Security Council Resolution No. S/2007/14 on 12 January 2007. Following the Resolution from the United Nations Human Rights Council as the fact-finding mission on the Rakhine discord on 26 March 2017. While the United Nations sent a fact-finding group in January 2017 after the conflict intensification in 2016, the two United Nations resolutions have not yet achieved problem solving function because of many hurdles in effecting the resolutions. ${ }^{5}$

The complexity of the policy making mechanism entomb The United Nations. The United Nations Security Council under the authority of the Charter of the United Nations 1945 knows that they pose an ability to take action and sanction on Rohingya humanitarian calamity. The classical issue on implementing those is still the 'national interests' of United Nations permanent members, given the fact that resolutions issued by the United Nations General Assembly and the UN Human Rights Council are only recommendations

M. Tanzimuddin Khan, "Dealing with the Rohingya crisis: The Relevance of the General Assembly and R2P", Asian Journal of Comparative Politics, Vol. 20, No. 10,2019 , p. 12 lbid. 
The Failure of United Nations System under International Law: Its Contribution to

Calamity and Ruin of the Rohingya Case

for programs of the UN Secretariat General. ${ }^{6}$

The 2007 Security Council of United Nations resolution with special attention to the humanitarian conflict in Rakhine flopped since it did not find an accord from all permanent members of the Security Council. Documented under the release of the United Nations Security Council meeting number S/PV.5619 on 12 January 2007, the United Kingdom, the United States, Belgium, France, Italy, Panama, Ghana, Peru and Slovakia accepted the resolution; whereast China Republic and Russia raised a veto; South Africa refused; while Indonesia, Qatar and Congo abstained. In the repossession mechanism on the United Nations Security Council, a resolution is agreed and can be applied should there remain nine countries that agree. Nevertheless, with a veto from Russia and China as Security Council permanent members, the status of this resolution is now thwarted. ${ }^{7}$

Wang Guangya, Chinese Ambassador to the United Nations asserted that problems in Myanmar is an internal affair of Myanmar as a sovereign state. The Myanmar government and the conflicting groups ought to be provided room to take out their own settlement endeavors. Whilst the Churkin, Russian Ambassador to the United Nations Vitaly, declared that the case is better handled by other United Nations agencies i.e World Health Organization or institutions that are focused on the field of human rights, not the United Nations Security Council per se. ${ }^{8}$

The Rohingya case is a case that has captured the interest of the international community. In Myanmar's Rhakine state, there remain over 1 million Rohingya who are mostly Muslim ethnic group for

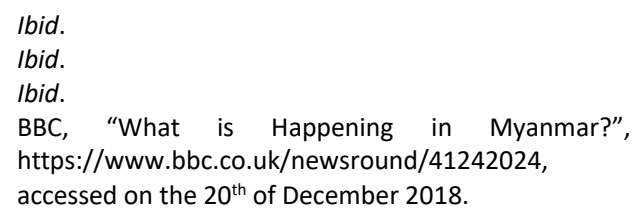

generations (a group of people sharing a same cultural background). On the other hand, most Myanmar's inhabitants is Buddhis. Numerous of the leading figures in the armed forces are Buddhist. The Rohingya people reveal they have been treated badly by Myanmar's government and military for many years while Myanmar government exclaims the Rohingya people as illegal immigrants from Bangladesh who are not in the right place in Myanmar. ${ }^{9}$ Therefore, the government acts not to recognise them as owning citizenship of Myanmar. They cannot get into the same medical treatment, schooling and rudimentary services as. The United Nations even has described them as one of the most persecuted populations in the world. ${ }^{10}$

More than 10,000 people were murdered, 720,000 escaped to Bangladesh according to the United Nations report, and it appealed for military leaders to be prosecuted in an international tribunal for "enocide, crimes against humanity and war crimes'."11 The United Nations asserted the Rohingya's situation as 'world's fastest growing refugee crisis'. The majority of Rohingya refugees who have arrived in Bangladesh have found shelter, setting up camp anywhere they can in the harsh climate, with minimal access to aid, clean drinking water, education, and healthcare. ${ }^{12}$ Since taking power in 2015, the world has placed pressure on Aung San Suu Kyi to do more in terms of campaigning. Aung San Suu Kyi, on the other hand, has no influence over the military. However, by refusing to criticize well-documented military crimes, she gives diplomatic protection to the generals. Her diplomats are coordinating with Russia and the UN to avert a Security Council vote of no confidence in the country, and she

11 Rebecca Wright, "Return to Rakhine: Genocide Never Happened in This Country", Loc.Cit.

12 BBC, "Myanmar Rohingya: What You Need to Know About the Crisis", https://www.bbc.com/news/worldasia-41566561, accessed on the $20^{\text {th }}$ of December 2018. 
described the recent violence as a "terrorist problem.". ${ }^{13}$

\section{B. THE PRIMARY RESPONSIBILITY OF INTERNATIONAL ORGANIZATION TO MAINTAIN WORLD PEACE AND SECURITY}

The word "international organisation" refers to a community created by two or more countries choosing to cooperate jointly. International organisations have existed since 1815 , but it is only since the First World War that they have gained significant political clout. Perhaps more recent is the notion that they have an international legal personality. ${ }^{14}$

When states found more productive ways to deal with issues created by the rapid growth of world society, international organizations emerged from diplomatic conferences in the 19th century. In the 1980s, the International Telegraphic Union and the Universal Postal Union were created. ${ }^{15}$ Many of the hundreds of international organisations existing today focus on technical, specialized subject areas, providing continuity and expertise with respect to the issues within their mandate. ${ }^{16}$ Nowadays, there are international organizations, such as the United Nations and its special organs, the European Union, and the International Whaling Commission, that have global obligations with very nearly universal membership. ${ }^{17} \quad$ Global international organisations designed to address broader issues, such as social welfare and the use of force. The works of ancient Greek and Roman philosophers include concepts concerning peaceful universal unions of citizens. Erasmus, Thomas More, Jean

13 Fergal Keane, "The Rohingya Crisis: Why Won't Aung San Suu Kyi Act?", https://www.bbc.com/news/worldasia-41187517, accessed on the $20^{\text {th }}$ of December 2018

14 Peter Malanczuk, Akehurst's Modern Introduction to International Law, London \& New York: Routledge, 1997, p. 92.

15 Anthony Aust, Handbook of International Law, New York: Cambridge University Press, 2005, p. 196.
Jacques Rousseau, Immanuel Kant, and Jeremy Bentham were among the European political theorists who conceived and advocated utopian ideas concerning international organizations. ${ }^{18}$ Although each organisation is different and must be studied separately, they share the following basic characteristics, such as, "treaty establishment", "membership limited exclusively or primarily to states", "international legal personality separates from its members", "financed by the members", and "permanent secretariats". ${ }^{19}$

Many international organizations have three primary organs, one of which is the assembly, which all members are entitled to join. Second, there is the executive body, with limited membership. Finally, this is the secretariat. These organs must be separated from the organization itself (and its specialized agencies i.e United Nations specialized agencies). ${ }^{20}$

The United Nations is a global body that brings together independent countries to advocate for world peace and social change. In 1945, the Organization was founded, with 51 countries as founding members. The United Nations had expanded to 192 countries by the end of 2008. No nation has ever been kicked out of the organization since its inception. Indonesia left the United Nations for a period in 1965 due to a disagreement with Malaysia but returned the following year. The United Nations does not represent any single government or country. It serves all of its members and only does what the member states ask it to.

The notion of a United Nations started to take shape during the years 1939-1945. Global leaders who came together to end the war saw a clear need for a process to help restore peace and deter possible wars.

16 Mark Janis (et.al), International Law Cases and Commentary, USA: Thomson West Publishing, 2005, p. 466.

17 Anthony Aust, Handbook of International Law, Loc.Cit.

18 Mark Janis (et.al), Loc.Cit.

$19 \quad$ Ibid, pp. 196- 197.

20 Anthony Aust, Op.Cit., p. 197 
World leaders discovered that the best way to succeed is for all nations to collaborate in a multinational body.

The United Nations Headquarters is an international zone, which ensures that the property on which the UN is situated belongs to all UN Members, not only the United States as the host country. The United Nations has its own flag and security officers to protect the region. It also maintains its own post office and issues stamps. Only UN Headquarters and UN offices in Vienna and Geneva will use these stamps. ${ }^{21}$ The United Nations Charter was signed in San Francisco on June 26, 1945, at the close of the United Nations Conference on International Organization, which went into effect on October 24, 1945. The International Court of Justice Statute is incorporated into the Charter. ${ }^{22}$

The General Assembly, Security Council, Economic and Social Council, Trusteeship Council, International Court of Justice, and Secretariat are the six institutions of the United Nations. The UN Headquarters in New York houses these organs. The International Court of Justice, which is based in The Hague, Netherlands, is an exception. These organs are involved in a wide range of activities, including medicine, agriculture, telecommunications, and weather. In addition, there are 24 services, trusts, and other entities with unique obligations. The United Nations framework is made up of these organizations and specialized agencies. ${ }^{23}$

In this paper, three main bodies of the United Nations will be discussed, namely general assembly, secretariat general, and security council of the United Nations, as well as the reform of the security council to become an international organization which is fair to all countries and able to

\footnotetext{
21 United Nations Department of Public Information New York 2008, "Everything You Always Wanted To Know About United Nations", pp. 8-9, http://unicir.org/Engaboutun.pdf, accessed on the $21^{\text {st }}$ of December 2018.

22 Ibid.

$23 \quad$ Ibid.
}

maintain international security and peace. These three organs are interrelated in carrying out their duties.

\section{Security Council}

Article 24(1) of the United Nations Charter bestows on the Security Council that, "the primary responsibilities for the maintenance of international peace and security, and the members agree that in carrying out the duties this entails the council acts on their behalf." 24

The membership of the UN Security Council is divided into permanent and non-permanent members. Members of the UN Permanent Security Council ${ }^{25}$ consist of 5 main countries which won World War II. The Five Permanent Members of the UN Security Council are called P5 (Permanent Five) and have Veto Rights so that they can cancel the decision or Resolution of the UN Security Council, even though the decision or resolution has been approved by all other members. ${ }^{26}$

UN Security Council has functions, namely, "to maintain international peace and security in accordance with the principles and objectives of the United Nations, to investigate and resolve any disputes or situations that lead to international disputes, to regulates how to settle each dispute or settlement conditions, to formulate a plan for the establishment of a system to regulate weapons, to establish situations that threaten peace or aggression and determine what steps to take, to convene to impose economic sanctions and other measures to prevent the use of force or stop aggression, to take military action

24 David Ott, Public International Law in The Modern World, London: Pitman, 1987, p. 359.

25 Article 23 (1) of United Nations Charter.

26 United Nations, "Current Member of The United Nations Security Council", http://www.un.org/en/sc/members/, accessed on the $21^{\text {st }}$ of December 2018. 
against aggressors, to provide recommendations for the acceptance of new UN members and give consideration to the membership of the International Court of Justice, to carry out guardianship functions in strategic areas, and lastly to provide recommendations to the General Assembly to appoint the UN Secretary General and together with the General Assembly to elect judges of the International Court of Justice." 27

Veto rights are regulated in Article 27 of the Charter, namely, "(1). Each member of the Security Council shall have one vote; (2). Decisions of the Security Council on procedural matters shall be made by an affirmative vote of nine members; (3). Decisions of the Security Council on all other matters shall be made by an affirmative vote of nine members including the concurring votes of the permanent members; provided that, in decisions under chapter VI, and under paragraph 3 of Article 52, a party to a dispute shall abstain from voting. " 28

The Security Council is given special powers under chapter VII of the charter to act on behalf of all states, even if it is intended to use force itself. To now, the system has not worked in practice and even at a time when the Security Council is more active in the maintenance of international peace and security, the original charter scheme is not fully implemented. ${ }^{29}$ Under article 39 of the charter, if the Security Council determines that if there is any "threat to the peace, breach of the peace, or act of aggression", temporary measures might be required to await a decision under article 39. Therefore, it is very important to know what kind of behavior is included in article 39 as this is a prerequisite for the exercise of this

27 Marthinus Omba, "Tanggung Jawab dan Peranan Dewan Keamanan PBB Dalam Memelihara Perdamaian Dan Keamanan Internasional", Jurnal Hukum Internasional, Vol. 5, No. 4, Juli, 2008, pp. 775- 776. law enforcement authority. In this respect, the General Assembly's definition of aggression will help, although it cannot increase or decrease the provisions of the charter itself. ${ }^{30}$

There have been armed attacks against the sovereign state and requests for assistance from the legitimate government have been made. However, as already stated, self defense under article 51 can only be taken until the Security Council has taken the necessary measures to restore international peace and security. The Security Council is able to restore international peace and security, but many countries argue that the simple fact that council resolutions have been passed does not mean that peace and security are guaranteed. We must remember that the goals of collective self defense and security are also different. Self defense is an emergency response to an emergency situation, but it also implies that the defender has the right to use force while being threatened and as long as his territory remains occupied. On the other hand, collective security is concerned with the maintenance of international peace and security and this may or may not mean the full justification of the rights of states, which are attacked illegally. It is often forgotten that the goals of collective self defense and collective security are not synonymous in practice or law.

Although we have focused on the Security Council's use of force as part of its collective security function, it has become clear in recent years that the Council has assumed the power to recommend or pass various measures in pursuit of collective security. It does not fit well into the category of military or nonmilitary sanctions, but remains

28 United Nations Charter 1945

29 Martin Dixon, Textbook on International Law, United Kingdom: Oxford University Press, 2007, pp. 342- 346. 
The Failure of United Nations System under International Law: Its Contribution to

Calamity and Ruin of the Rohingya Case

enforced under chapter VII based on the implied strengths developed in council practice. Thus the Security Council can initiate and organize peacekeeping force operations, either sent with the consent of the disputing parties (which do not require a decision under chapter VIII) or imposed on the parties under chapter VII without their consent. Likewise, the Security Council appears to be able to impose all kinds of additional obligations on countries that are in arrears after being subdued by enforcement action.

\section{General Assembly}

The General Assembly is the United Nations' deliberative organ, decision maker, and principal representative. A two-thirds vote is required for important questions such as peace and stability, recruiting, and budget issues. Other questions are decided by a simple majority vote. Each nation is entitled to one vote. Any Member States could be denied the right to vote if they are in arrears of their payments. ${ }^{31}$ The General Assembly is made up of all United Nations members. Non-member countries whose delegates are named to attend General Assembly sessions at the United Nations are merely visitors. The organ gathers for hearing once a year, normally on the third Tuesday in September, and usually at the United Nations headquarters in New York. ${ }^{32}$

Articles 9-22 of the UN Charter gives power to the General Assembly as one of UN main organs, the general assembly, is composed of delegates from all member states (article 9 paragraph 1). Within its capabilities, the General Assembly has the authority to

United Nations, "The Definition of General Assembly", http://www.un.org/en/ga/about/>, accessed on the $21^{\text {st }}$ of December 2018.

32 Ade Maman Suherman, Organisasi Internasional \& Integrasi Ekonomi Regional dalam Perspektif Hukum dan Globalisasi, Jakarta: Ghalia Indonesia, 2003, p. 116. make recommendations to States on international matters. It has also taken action on political, economic, humanitarian, social, and legal issues that have impacted millions of people all over the world. The landmark Millennium Declaration, adopted in 2000, and the 2005 World Summit Outcome Document, reflect the commitment of Member States. ${ }^{33}$

\section{Secretariat}

Other main organs of the Secretariat of the UN. As the organ that regulates and coordinates the activities of the United Nation, and chaired by the Secretary General of the United Nations, the UN Secretariat impacts the work of the United Nations to a much greater extent than is indicated in the Charter of the United Nations. ${ }^{34}$ In addition to reading, interpreting, and delivering facilities for a wide range of meetings and other jobs, they are responsible for conducting numerous analyses, surveys, and inquiries. Despite deliberate attempts to recruit people from numerous regional regions, employees would be employed solely on merit under the Charter. Such Secretariat members are employed on a permanent basis, while others are employed on a provisional basis by their national government. They must pledge loyalty to the United Nations in all situations and are not entitled to accept orders from member governments. The Secretariat's clout stems from the fact that almost 9,000 of its employees are permanent consultants and diplomatic civil servants, rather than officially

33 United Nations, "Functions and Powers of The General Assembly",

http://www.un.org/en/ga/about/background.shtml, accessed on the $21^{\text {st }}$ of December 2018.

34 Britannica, "Secretariat United Nations", https://www.britannica.com/topic/Secretariat-UN, accessed on the $23^{\text {rd }}$ December 2018. 
selected representatives from member states. ${ }^{35}$

The Secretary-General is the United Nations' main administrative officer, chosen by two-thirds of the General Assembly on the advice of the Security Council and with the consent of its permanent members for a five-year term. ${ }^{36}$ To be elected to that role, this organ must receive the approval of the P5 members of the Security Council. The general secretary is generally from a small, neutral nation for this purpose. ${ }^{37}$ It also oversees the preparation of the UN budget. The secretary general has a significant political role, as he is responsible for bringing matters to the attention of organisations that pose a danger to international peace and stability. As the UN's principal spokesperson and the most visible and authoritative UN figure in international affairs, this organ regularly acts as a high-level negotiator. ${ }^{38}$

\section{THE FAILURE OF THE UNITED NATIONS TO MAINTAIN WORLD PEACE}

In general, the UN's key goal is to protect mankind from the outbreak of war by enforcing clauses in the UN Charter that ensure universal peace and stability. ${ }^{39}$ To accomplish this aim, the UN takes effective collective steps to deter and avoid the possibility of violence or other breaches of peace, as well as to pursue settlement by diplomatic means, in line with international law and justice principles. ${ }^{40}$

The Charter of the United Nations grants states the right to submit a situation that threatens world peace and stability to the Security Council, but the Security Council is usually unable to take effective

35 Britannica, "United Nations Principal Organs", https://www.britannica.com/topic/UnitedNations/Principal-organs\#ref368944, accessed on the $23^{\text {rd }}$ of December 2018

36 Ibid.

37 Britannica, "Secretariat United Nations", Loc.Cit.

38 Britannica, "United Nations Principal Organs", Loc. Cit. resolution. The inability of the League of Nations to avert World War II was reaffirmed by the United Nations Security Council in this case. The development of a peace resolution has been stalled by numerous conflicts of interest among permanent members of the UN Security Council. Based on Article 27 of the United Nations Charter, these 5 permanent member countries have veto powers. According to data gathered by The Statistics Portal, precisely 220 veto rights were enacted between January 25, 1946 (the first time the UN Security Council Resolution was passed) and August 2017. The USSR has been blocked the most resolutions in all, with 90 vetoes, primarily on UN membership applications and admissions to the UN. ${ }^{41}$

Looking at the historical evidence, it is clear that disputes between countries with interests of permanent members of the UN Security Council are more complex to resolve than conflicts between countries with no interests in permanent members of the UN Security Council. When comparable situations containing challenges to the international community's stability and peace occurred without intervention by permanent members of the UN Security Council, it was assumed that this was unjust. Resolution 2127 (2013) of the United Nations Security Council is the first example This resolution was needed in order to send troops from Africa and France to the Central African Republic to deal with the crisis. None of the leaders of the UN Security Council objected and bought it in the resolution. Similarly, in 2015, the United Nations Security Council passed Resolution 2206 in South Sudan. The UN Security Council voted to expand a peacekeeping operation in Darfur to protect civilians and

39 Sumaryo Suryokusumo, Organisasi Internasional, Jakarta: UI-Press, 1987, p. 8.

40 United Nations Charter

41 Isabel von Kessel, "Who Vetoed the Most in the UN?", https://www.statista.com/chart/10758/un-securitycouncil-resolutions-vetoed/, accessed on the $21^{\text {st }}$ of December 2018 
ensure aid supply, despite the Sudanese government's opposition to the US $\$ 1.1$ billion mission. ${ }^{42}$ The two examples above are similar that there is no conflict of interest among members of the UN Security Council. As a result, both representatives decided and there was no veto. Since these organizations are given the power to address humanitarian crises which endanger world stability, this is what the international community really wants for the Security Council. Despite the fact, the system is not completely useless. A few academics continue to believe that bringing a conflict to the Security Council is necessary, not to resolve the dispute, but to rally the international community's public opinion. ${ }^{43}$

Applying the aforementioned analysis to the Rohingya situation. In Spite Of horrific violations, the irony of the Rohingya crisis is that the international community and the UN have refused to recognize the tragedy in a timely manner. If the situation is described as 'genocide', textbook definition of ethnic cleansing, the organisation is morally and ethically obligated to intervene, at the very least by peacekeeping missions. Nonetheless, the UN Security Council's response was woefully inadequate. Instead of a full weapons embargo, which would have given a stronger warning to Myanmar's military to stop the attack that has resulted in 700,000 refugees, the UN session provided nothing but clichés. A Security Council that is incapable of preventing massacres, ethnic cleansing, and human rights violations. ${ }^{44}$

Myanmar has been urged by the UN Security Council to stop the abuse, but no

42 Ike Agestu, "PBB Perpanjang Misi Perdamaian di Darfur"

https://www.cnnindonesia.com/internasional/20150 630075753-134-63170/pbb-perpanjang-misi-

perdamaian-di-darfur, accessed on the $24^{\text {th }}$ of December 2018.

43 Sumaryo Suryokusumo, Op.Cit., p. 21.

44 Hammad Zamurrad, "How the United Nation failed The Rohingya People", http://theasiadialogue.com/2018/03/07/how-the-unfailed-the-rohingya-people/, accessed on the $23^{\text {rd }}$ of December 2018. sanctions have been implemented. That is the primary obstacle to world peace. The Council's overhaul is part of a wider UN reform initiative to create a more successful and inclusive global organization. Other bodies, such as the General Assembly, can be reformed as part of the organization's management change. ${ }^{45}$ Notwithstanding its special importance and legitimacy in attempts by nations to preserve world stability and stability, the United Nations Security Council is generally recognized as having a poor track record. The Council is in desperate need of restructuring. At the conclusion of World War II, the United Nations Security Council has played a pivotal role in the conduct of global diplomatic affairs. Although the world community has shifted dramatically over that period, largely due to decolonization and the disintegration of the Soviet Union, the Security Council has remained essentially unchanged. ${ }^{46}$

The veto authority is a critical feature of the privileged and accountable role given to the Permanent Members of the Security Council by the Charter. Any of them has the authority to veto any substantive Council vote. The eleven-member Security Council formed in San Francisco was to be made up of five permanent members and six elected members. The United States, the United Kingdom, France, the Republic of China, and the Federation of Soviet Socialist Republics became the five permanent representatives. These were the so-called World War II victor powers. The members of the Council will be elected for a two-year term. Since they were willing to effectively appeal against strenuous resistance, the

45 Global Policy Forum, "Security Council Reform",https://www.globalpolicy.org/securitycouncil/security-council-reform.html, accessed on the $24^{\text {th }}$ of December 2018.

46 Richard Butler, "Reform of the United Nations Security Council", Penn State Journal of Law and International Affairs, Vol. 1, No. 1, 2012, pp. 23- 24.

Available at:

https://elibrary.law.psu.edu/cgi/viewcontent.cgi?artic $l e=1001 \&$ context $=$ jlia 
Permanent Five were awarded their permanency and the exceptional right of veto. Without both rights, there will be no new Organization. ${ }^{47}$

The vetoes used by Russia and the United States were often used during the Cold War, and they were used to shield their client states. For eg, Russia often vetoed on behalf of Eastern European clients, while the US frequently vetoed on behalf of Israel. Finally, the "cascade effect" has been attributed to permanent membership of the Security Council and the veto power that comes with it. This absurdly innocuous concept attempts to explain the very real phenomenon of the Five being granted meaningful permanent membership status in nearly all other United Nations departments, Commissions, and Committees. ${ }^{48}$

In order to overhaul the Security Council, three major topics must be addressed. The first is the Security Council's constituency, which includes the number of people on the Council and how they can be voted or chosen. The Security Council's decision-making methodology is the second issue. This will entail the distinction between substantive and administrative issues, the voting and decision-making methodology to be used on both, and whether or not vetoes should be used.Third, the Security Council's overarching position in the United Nations' global management of international peace and security. This is not to say that the Council's primary duty should be radically revised. However, there is a need to resolve the so-called "cascade effect.". ${ }^{49}$

As we move from the agenda to the Security Council's decision-making record, we are faced with what could be the most glaring weakness. While the Council has had

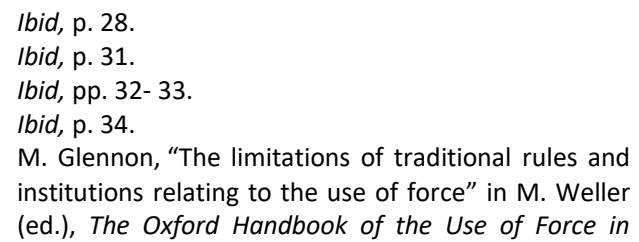

some successes, it is better known for its persistent inability to find a consensus on how to effectively deal with challenges to peace and stability. One of the main reasons for this has been the inability of one or more Permanent Members to put their own desires aside. It should not be appropriate to veto UN action against a state that is obviously in violation of international law and tradition because that state is an ally. This practice was never planned in San Francisco, and it could never be accepted in the modern world of politics. Nonetheless, this perspective has been acknowledged several times. The most egregious example of perpetual entitlement misuse is the use of ballots as favors. ${ }^{50}$

Article 39 of the UN Charter, which authorizes the UNSC to decide if a single event represents threat to international peace, breaches peace, or as an aggression, one of causes of the Council's inaction. As a result, the UNSC makes decisions on what actions or recommendations should be taken to preserve or restore international peace and stability. ${ }^{51}$ The Security Council permanent member then has broad discretion to consider the situation in Rohingya as a threat. This leaves the discussion whether the situation in Rohingya requires the UN Security Council to act or not. To this inability, UNGA states have adopted a remarkable R2P resolution. ${ }^{52}$ The resolution is extraordinary because R2P goes to discourse the glitches of the UN Charter concerning the non-interference norms, sovereignty, protection, and promotion of human rights. R2P delivers a new understanding of sovereignty by going outside the traditional definition of protecting territorial boundaries of states from aggression, and by defining it as the

International Law, Oxford: Oxford University Press, 2015, pp. 79-94.

52 Alex J. Bellamy and Paul D. Williams, "The new politics of protection? Côte d'Ivoire, Libya and the responsibility to protect", International Affairs, Vol. 87, No. 4, 2011, pp. 825-850. 
responsibility of a state to protect its people from all aggression.

R2P puts a duty on all the states to protect people from grave crimes, particularly when the state is unable to protect its own people. ${ }^{53}$ In line with R2P, UNSC unanimously has adopted Resolution 1674 (2006) reaffirming its commitment to protect people from genocide, war crimes, crimes against humanity. ${ }^{54}$ Though, UNSC has failed to implement the commitment in the case of Myanmar.

The UNGA should make a recommendation to UNSC to take actions to end violence in Rakhine State, and commence further investigation of legal methods to bring the perpetrators to justice, according to R2P. This can offset the policymaking unbalance within UNSC because of the interest and manipulation of permanent members. ${ }^{55}$ Although the principle of R2P is still in an embryonic UNSC is obligated to follow the R2P principle under its own Resolution 1674 2006). After the implementation of Resolution 1674 in 2006, the UNSC has used R2P for peacekeeping operations in Darfur (2006), Kenya (2007, 2008), Côte d'Ivoire (2011), Yemen (2011), Mali (2012, 2013), Sudan (2011), Libya (2011), and South Sudan (2013). The Libyan situation has been heavily criticized because many people see regime change as the main motivation for action, rather than the avoidance of mass atrocity crimes. Yet, Libya is the first time the UN Security Council has allowed military intervention to protect civilians without the permission of the host country. The tradition of obtaining the host country's permission as a precondition for any UN mission under the Chapter VII mandate has long been criticized, as it can lead to UN

$53 \quad$ Alex J. Bellamy, "The responsibility to protect -5 years on", Ethics and International Affairs, Vol. 24, No. 2, 2010, pp. 143-169.

54 Security Council Resolution 1674 (2006) on Protection of Civilians in Armed Conflict.

55 Mohammad Tanzimuddin Khan, "Dealing with the Rohingya crisis: The relevance of the general assembly and R2P", Asian Journal of Comparative Politics, Vol. 5, No. 2, 2019, p. 136 deployments being infrequent, and force being inflicted on non-state actors only amid awareness that government forces were equally responsible for civilian massacres.

Another alternative option for the UNGA is the "Uniting for Peace" resolution ${ }^{56}$ During the Korean War, it was used to enable the UN to participate. The UNSC was reluctant to take any intervention decisions at the time due to Cold War rivalries. This principle was then invoked by the UNGA. It states that if the UNSC fails to compromise on a topic, the UNGA will recognize it immediately and propose to all members joint action steps to restore international peace and stability in crisis situations. This mechanism could also be implemented by UNGA in the Rohingya situation. Within the Uniting for Peace resolution, UNGA can recommend military measures to be taken in Myanmar in order to halt deteriorating humanitarian conditions. This can be achieved by calling a special session under Chapter IV Article 20 or an emergency session under Resolution 377A (V) 'Uniting for Peace'. These sessions are held at the behest of the UNSC or a majority of the UNGA members.

Article 39 of the UN Charter, which authorizes the UNSC to decide if a single event represents threat to international peace, breaches peace, or as an aggression, one of causes of the Council's inaction. As a result, the UNSC makes decisions on what actions or recommendations should be taken to preserve or restore international peace and stability. ${ }^{57}$ The Security Council permanent member then has broad discretion to consider the situation in Rohingya as a threat. This leaves the discussion whether the situation in

56 Michael Ramsden, "Uniting for peace and humanitarian intervention: The authorizing function of the UN General Assembly", Washington International Law Journal, Vol. 25, No. 2, 2016, pp. 267-305.

57 Michael Glennon, The Oxford Handbook of the Use of Force in International Law, Oxford: Oxford University Press, 2015, pp. 79-94. 
Rohingya requires the UN Security Council to act or not. To this inability, UNGA states have adopted a remarkable R2P resolution. ${ }^{58}$ The resolution is extraordinary because R2P goes to discourse the glitches of the UN Charter concerning the non-interference norms, sovereignty, protection, and promotion of human rights. R2P delivers a new understanding of sovereignty by going outside the traditional definition of protecting territorial boundaries of states from aggression, and by defining it as the responsibility of a state to protect its people from all aggression.

R2P puts a duty on all the states to protect people from grave crimes, particularly when the state is unable to protect its own people. ${ }^{59}$ In line with R2P, UNSC unanimously has adopted Resolution 1674 (2006) reaffirming its commitment to protect people from genocide, war crimes, crimes against humanity. ${ }^{60}$ Though, UNSC has failed to implement the commitment in the case of Myanmar. The UNGA should make a recommendation to UNSC to take actions to end violence in Rakhine State, and commence further investigation of legal methods to bring the perpetrators to justice, according to R2P. This can offset the policymaking unbalance within UNSC because of the interest and manipulation of permanent members. ${ }^{61}$

Although the principle of R2P is still in an embryonic UNSC is obligated to follow the R2P principle under its own Resolution 1674 2006). After the implementation of Resolution 1674 in 2006, the UNSC has used R2P for peacekeeping operations in Darfur (2006), Kenya $(2007,2008)$, Côte d'Ivoire (2011), Yemen (2011), Mali (2012, 2013), Sudan (2011), Libya (2011), and South Sudan (2013). The Libyan situation has been heavily criticized because many people see regime change as the main motivation for action, rather than the avoidance of mass atrocity crimes. Yet, Libya is the first time the UN Security Council has allowed military intervention to protect civilians without the permission of the host country. The tradition of obtaining the host country's permission as a precondition for any UN mission under the Chapter VII mandate has long been criticized, as it can lead to UN deployments being infrequent, and force being inflicted on non-state actors only amid awareness that government forces were equally responsible for civilian massacres.

Another alternative option for the UNGA is the "Uniting for Peace" resolution ${ }^{62}$ During the Korean War, it was used to enable the UN to participate. The UNSC was reluctant to take any intervention decisions at the time due to Cold War rivalries. This principle was then invoked by the UNGA. It states that if the UNSC fails to compromise on a topic, the UNGA will recognize it immediately and propose to all members joint action steps to restore international peace and stability in crisis situations. This mechanism could also be implemented by UNGA in the Rohingya situation. Within the Uniting for Peace resolution, UNGA can recommend military measures to be taken in Myanmar in order to halt deteriorating humanitarian conditions. This can be achieved by calling a special session under Chapter IV Article 20 or an emergency session under Resolution 377A (V) 'Uniting for Peace'. These sessions are held at the behest of the UNSC or a majority of the UNGA members.

$58 \quad$ Alex J. Bellamy, "The new politics of protection? Côte d'Ivoire, Libya and the Responsibility to Protect", The Royal Institute of International Affairs, Vol. 87, No. 4, 2011, pp. 825-850.

59 Alex J.Bellamy, "The Responsibility to Protect-Five Years On", Cambridge University Press, Vol. 24, No. 2, 2010, pp. 143-169.

60 Security Council Resolution 1674 (2006) on Protection of Civilians in Armed Conflict (S/RES/1674/2006).

61 Mohammad Tanzimuddin Khan, Op.Cit., p. 136

62 Michael Ramsden,"Uniting for peace and humanitarian intervention: The authorizing function of the UN General Assembly", Washington International Law Journal, Vol. 25, No. 2, 2016, pp. 267-305. 
The Failure of United Nations System under International Law: Its Contribution to Calamity and Ruin of the Rohingya Case

\section{CONCLUSION}

The irony of the Rohingya crisis is that the international community and the UN have refused to recognize the tragedy in a timely manner. Security Council incapable of preventing massacres, ethnic cleansing, and human rights violations. ${ }^{63}$ The veto authority is a critical feature of the privileged and accountable role given to the Permanent Members of the Security Council by the Charter. Any of them has the authority to veto any substantive Council vote. Although UNGA states have adopted a remarkable R2P resolution and UNSC unanimously has adopted Resolution 1674 (2006) reaffirming it. UNSC has failed to implement the commitment in the case of Myanmar. UNGA's contribution to Rohingya deteriorating situation is its failure to take "Uniting for Peace" resolution. Reforming the UN security council becomes an urgency. In conclusion, members of the security council must still be expanded, as well as a security council that does not necessarily need to be added, in order to achieve international justice. Veto rights should not conflict with the substance, function and role of the security council to maintain international peace and security, and protect human rights, such as in spiritual cases. Although Aung San Suu Kyi's diplomats are working with Russia, it does not mean that Russia can veto the resolution of the security council to punish Myanmar for the Rohingya case, solely due to political reasons. Because what happens in Rohingya, is a heavy international crime against human rights and is hostis humanis generis.

Genocide as an action vanishing group of people because of its religion, race, ethnicity, nationality in Rohingya clearly has attracted the international community Most Rohingyan are Muslim and there are settled in the Rakhine state for many generations. However, the Myanmar

Hammad Zamurrad, "How the United Nation failed The Rohingya People", http://theasiadialogue.com/2018/03/07/how-the-un- government does treat them unequally and refused to acknowledge Rohingya people as citizens of Myanmar since long ago. Consequently, Rohingyan's does not have access to medication, education, and other basic government services. Rohingya genocide described as a catastrophe against humanity, and the UN mentioned particularly as 'the world's most prosecuted people.' The Rohingya crisis, in spite of the horrendous abuses, the irony is that the broader international community and the UN have failed to take necessary action to prevent Rohingyan's genocide. Exploring the existing historical facts, it can be seen that the conflict of countries that have interests with members of the UN Security Council is more difficult to solve than conflicts that do not involve the interests of the parties. For the fact is Aung San Suu Kyi's diplomats are working with Russia and the UN to prevent criticism of the government at Security Council level, and she herself has characterised the latest violence as a problem of terrorism, and Russia is the permanent member of Security Council.

\section{REFERENCES}

\section{Books}

Aust, Anthony, Handbook of International Law, Cambridge University Press, New York, 2005.

Dixon, Martin, Textbook on International Law, Oxford University Press, United Kingdom, 2007.

Glennon, Michael The Oxford Handbook of the Use of Force in International Law, Oxford University Press, Oxford, 2015.

Janis, Mark (et.al), International Law Cases and Commentary, Thomson West Publishing, USA, 2005.

Malanczuk, Peter, Akehurst's Modern Introduction to International Law,

failed-the-rohingya-people/, accessed on the $23^{\text {rd }}$ of December 2018. 
Routledge, London \& New York, 1997.

Ott, David, Public International Law in The Modern World, Pitman, London, 1987.

Suherman, Ade Maman, Organisasi Internasional \& Integrasi Ekonomi Regional dalam Perspektif Hukum dan Globalisasi, Ghalia Indonesia, Jakarta, 2003.

Suryokusumo, Sumaryo, Organisasi Internasional, UI-Press, Jakarta, 1987.

\section{Other Documents}

Abdelkader, Engy, "The Rohingya Muslims in Myanmar: Past, Present, and Future", https://scholarsbank.uoregon.edu/x mlui/bitstream/handle/1794/17966/ Abdelkader.pdf.

Agestu, Ike, "PBB Perpanjang Misi Perdamaian di Darfur" https://www.cnnindonesia.com/inte rnasional/20150630075753-13463170/pbb-perpanjang-misiperdamaian-di-darfur.

BBC, "What is Happening in Myanmar?", https://www.bbc.co.uk/newsround/ 41242024.

BBC, "Myanmar Rohingya: What You Need to Know About the Crisis", https://www.bbc.com/news/worldasia-41566561.

Bellamy, Alex, "The Responsibility to Protect-Five Years On", Cambridge University Press, Vol. 24, No. 2, 2010.

Bellamy, Alex, "The new politics of protection? Côte d'Ivoire, Libya and the Responsibility to Protect", The Royal Institute of International Affairs, Vol. 87, No. 4, 2011.

Britannica, "Secretariat United Nations", https://www.britannica.com/topic/S ecretariat-UN.

Britannica, "United Nations Principal Organs", https://www.britannica.com/topic/U nited-Nations/Principalorgans\#ref368944.
Butler, Richard, "Reform of the United Nations Security Council", Penn State Journal of Law and International Affairs, Vol. 1, No. 1, 2012.

Global Policy Forum, "Security Council Reform", https://www.globalpolicy.org/securi ty-council/security-councilreform.html.

Human Rights Watch, "The Government Could Have Stopped This", http://www.hrw.org/reports/2012/0 8/01/government-could-havestopped.

Keane, Fergal, "The Rohingya Crisis: Why Won't Aung San Suu Kyi Act?", https://www.bbc.com/news/worldasia-41187517.

Kessel, Isabel von, "Who Vetoed the Most in the UN?", https://www.statista.com/chart/107 58/un-security-council-resolutionsvetoed/.

Khan, Mohammad Tanzimuddin, "Dealing with the Rohingnya crisis: The Relevance of the General Assembly and R2P", Asian Journal of Comparative Politics, Vol. 20, No. 10, 2019.

Mohajan, Haradhan Kumar, "History of Rakhine State and the Origin of the Rohingya Muslims", The Indonesian Journal of Southeast Asian Studies, Vol. 2, No. 1, 2018.

Omba, Marthinus, "Tanggung Jawab dan Peranan Dewan Keamanan PBB Dalam Memelihara Perdamaian Dan Keamanan Internasional", Jurnal Hukum Internasional, Vol. 5, No. 4, Juli, 2008.

United Nations Department of Public Information New York 2008, "Everything You Always Wanted To Know About United Nations", http://unic-ir.org/Engaboutun.pdf.

United Nations, "Current Member of The United Nations Security Council", http://www.un.org/en/sc/members/

United Nations, "Functions and Powers of The General Assembly", 
The Failure of United Nations System under International Law: Its Contribution to

Calamity and Ruin of the Rohingya Case

http://www.un.org/en/ga/about/ba ckground.shtml.

United Nations, "The Definition of General Assembly", http://www.un.org/en/ga/about/.

Wright, Rebecca, "Return to Rakhine: Genocide Never Happened in This Country", https://edition.cnn.com/2018/10/17 /asia/inside-rakhine-stateintl/index.html.

Zamurrad, Hammad, "How the United Nation failed The Rohingya People", http://theasiadialogue.com/2018/03 /07/how-the-un-failed-the-rohingyapeople/.

\section{Legal Documents}

Convention on the Prevention and Punishment of the Crime of Genocide.

United Nations Charter 1945.

and Punishment of the Crime of Genocide United Nations Charter. 